\title{
Politik Hukum Hak Asasi Manusia Tentang Kebebasan Beragama Pasca Orde Baru
}

\author{
Suparman Marzuki \\ Fakultas Hukum Universitas Islam Indonesia \\ Jln. Taman Siswa No. 158 Yogyakarta \\ mzpushamuii@yahoo.com
}

Received: 10 September 2017; Accepted: 12 Mei 2018; Published: 22 Agustus 2019

DOI: 10.20885 /iustum.vol26.iss2.art1

\begin{abstract}
This research aims to uncoven and describe: first, the policy of state regulation in order to fulfil the right to religious freedom. Second, the concrete actions of state in taking legal steps against violations of religious freedom. This research utilizes a normative juridical method where data is collected from documents. The outcome of this research concludes that: first, Political Human Rights on the freedom of religion in Indonesia following the new order at the level of fulfilment in the form of legislation is relatively more advance and protective. Second, the strengthening of Political Human Rights at the regulatory level is not followed by changes in the legislation below it such as PNPS Law No.1 of 1965 and Article 156(a) of the Indonesian Criminal Code regarding blasphemy. Therefore, it can be concluded that Political Human Rights in Indonesia, particularly relating to the freedom of religion is a paradox. On one side it supports the products of laws and regulation which further strengthen the rights to the freedom of religion and beliefs, but on the other hand, realistically, the State actually fails to protect various forms of violations of the right to the freedom of religion and beliefs.
\end{abstract}

Keywords: Freedom of religion; human rights; legal policy

\section{Abstrak}

Penelitian ini bertujuan untuk menemukan dan mendiskripsikan tentang: pertama, kebijakan regulasi negara dalam rangka memenuhi hak kebebasan beragama, serta kedua, tindakan konkrit negara dalam mengambil langkah hukum terhadap pelanggaran kebebasan beragama. Penelitian ini menggunakan metode penelitian yuridis normatif melalui dokumen-dokumen. Hasil penelitian membuktikan bahwa pertama, politik hukum HAM tentang kebebasan beragama di Indonesia pasca Orde Baru di level pemenuhan berupa pembuatan peraturan perundang-undangan relatif lebih maju dan protektif. Kedua, menguatnya politik hukum HAM di tingkat regulasi tidak diikuti dengan perubahan peraturan perundangundangan di bawahnya, seperti UU PNPS No. 1 Tahun 1965 dan Pasal 156a KUHP, terkait dengan peraturan penistaan agama. Sehingga dapat disimpulkan bahwa politik hukum HAM di Indonesia terutama terkait dengan kebebasan beragama berwajah paradoksal. Satu sisi menguat produk peraturan perundang-undangan yang lebih menguatkan pemenuhan hak kebebasan beragama dan berkeyakinan, tetapi di sisi lain (realitasnya) negara justru gagal melindungi pelbagai bentuk pelanggaran terhadap hak kebebasan beragama dan berkeyakinan.

Kata-kata Kunci: Politik hukum; hak asasi manusia; kebebasan beragama 


\section{Pendahuluan}

Studi tentang politik hukum di Indonesia baik di level legislasi maupun implementasi di pusat maupun di daerah pada pelbagai aspek peraturan perundang-undangan sudah banyak dilakukan oleh para akademisi dan peneliti pada umumnya. Riset-riset tersebut menghasilkan temuan-temuan penting yang menggambarkan dasar, motif, tujuan dan sebab-sebab tidak berjalannya peraturan perundang-undangan. Begitu pula penelitian di bidang hukum hak asasi manusia dengan ragam isu HAM di bidang hak sipil politik maupun hak ekonomi, sosial dan budaya telah pula mewarnai riset HAM sejalan dengan banyaknya konvensi HAM internasional yang telah di ratifikasi Indonesia. ${ }^{1}$

Secara konseptual, politik hukum adalah kebijakan (policy) negara melalui badan-badan negara yang berwenang menetapkan peraturan-peraturan yang dikehendaki, ${ }^{2}$ yang diperkirakan akan digunakan untuk mengeksperesikan apa yang terkandung dalam masyarakat dan untuk mencapai apa yang dicita-citakan, ${ }^{3}$ atau untuk mewujudkan peraturan-peraturan yang baik sesuai dengan keadaan dan situasi pada suatu waktu. ${ }^{4}$

Politik hukum bisa pula bermakna sebagai aktivitas memilih dan cara yang hendak dipakai untuk mencapai suatu tujuan sosial dan hukum tertentu dalam masyarakat; 5 atau kebijakan hukum (legal policy) yang hendak diterapkan atau dilaksanakan oleh suatu pemerintahan negara tertentu; ${ }^{6}$ atau alat (tool) dan langkah yang dapat digunakan oleh pemerintah untuk menciptakan sistem hukum nasional yang dikehendaki dan dengan sistem hukum nasional itu akan diwujudkan citacita bangsa Indonesia. ${ }^{7}$

1 Antara lain: Konvensi Hak Anak - Convention on the Rights of the Child. Telah diratifikasi dengan Kepres 36 tahun 1990; Konvensi Menentang Penyiksaan dan Perlakuan atau Penghukuman Lain yang Kejam, Tidak Manusiawi, atau Merendahkan, atau merendahkan martabat Manusia - Toture Convention. Telah diratifikasi dengan UU No. 5 tahun 1998; Konvensi Internasional tentang Penghapusan Semua Bentuk Diskriminasi Rasial Convention on the Elemination of Racial Discrimination. Telah diratifikasi dengan UU No. 29 Tahun 1999; Kovenan Internasional tentang Hak-Hak Ekonomi, Sosial, dan Budaya dengan Undang-Undang No.11/2005; Kovenan Internasional tentang Hak-Hak Sipil dan Politik dengan Undang-Undang No.12/2005.

${ }^{2}$ Legislatif dan atau eksekutif pusat dan daerah.

${ }^{3}$ Soedarto, Hukum Pidana dan Perkembangan Masyarakat dalam Kajian Hukum Pidana, Sinar Baru, Bandung, 1983, hlm. 20.

${ }^{4}$ Soedarto, Hukum dan Hukum Pidana, Alumni, Bandung, 1986, hlm. 151.

5 Satjipto Raharjo, Ilmu Hukum, Citra Aditya Bakti, Bandung, 2000, hlm. 35.

${ }^{6}$ Mahfud MD, Membangun Politik Menegakean Konstitusi, Rajawali Pers, Jakarta, 2010, hlm. 15.

${ }^{7}$ Sunaryati Hartono, Politik Hukum Menuju Satu Sistem Hukum Nasional, Alumni, Bandung, 1991, hlm. 1. 
Faktor-faktor yang akan menentukan politik hukum tidak semata-mata oleh apa yang kita cita-citakan atau tergantung pada kehendak pembentuk hukum, praktisi atau para teoritisi belaka, akan tetapi ditentukan pula oleh kenyataan serta perkembangan hukum di lain-lain negara serta perkembangan hukum internasional ${ }^{8}$.

Cakupan politik hukum tidak saja proses pembuatan (law making) tetapi juga pelaksanaan hukum (law enforcement). Keduanya dapat menunjukkan sifat dan ke arah mana hukum akan dibangun; sekaligus memberikan landasan terhadap proses pembentukan hukum yang lebih sesuai dengan situasi dan kondisi, kultur serta nilai yang berkembang di masyarakat dengan memperhatikan kebutuhan masyarakat terhadap hukum itu sendiri. ${ }^{9}$

Politik hukum HAM dalam konteks penelitian ini adalah bagaimana kebijakan negara (Republik Indonesia) ${ }^{10}$ tentang tanggungjawabnya melaksanakan kewajiban memenuhi (to fulfill) yaitu melakukan langkah-langkah regulasi dan deregulasi dalam upaya memenuhi hak sipil serta kewajiban melindungi (to protect) berupa kepastian negara mengambil langkah-langkah hukum dengan menggerakkan institusi penegak hukum bila terjadi pelanggaran terhadap hak-hak sipil manusia, terutama warganegara Indonesia. Termasuk dalam konsepsi ini memastikan negara tidak melakukan pelanggaran melanggar hak sipil secara sengaja (by commission) maupun pembiaran (by omission).

Sejalan dengan konsepsi-konsepsi di atas, politik hukum HAM tentang kebebasan beragama sebagai salah satu aspek dari hak sipil menarik untuk diteliti dan dianalisis guna menemukan data dan informasi mengenai kebijakan hukum tentang dan terhadap kebebasan beragama, khususnya di Indonesia paska Orde Baru yang dalam rentang waktu (1998-2018) memicu sejumlah konflik dalam masyarakat. ${ }^{11}$

${ }^{8}$ Ibid, 23.

${ }_{9}^{9}$ Mahfud MD, Politik Hukum Di Indonesia, Rajawali Pers, Jakarta, 2009, hlm. 9.

10 Politik hukum HAM Indonesia tentu saja harus berbasis pada ideologi Pancasila agar mencerminkan nilai-nilai Ketuhanan Yang Maha Esa, kemanusian yang adil dan beradab, persatuan indonesia, meletakkan kekuasaan di bawah kekuasaan rakyat, dan keadilan sosial bagi seluruh rakyat Indonesia, serta UUD 1945 sebagai basis konstitusional untuk mencapai tujuan kemerdekaan dan tujuan bernegara yaitu untuk melindungi segenap bangsa dan seluruh tumpah darah Indonesia, memajukan kesejahteraan umum, mencerdaskan kehidupan bangsa, melaksanakan ketertiban dunia berdasarkan kemerdekaan, perdamaian abadi dan keadilan sosial.

11 Setara Institute dalam Laporan Tahunannya mencatat terjadi 155 kasus selama tahun 2017. 
Menarik dan pentingnya isu ini diangkat adalah terutama karena realitas pemenuhan (to fulfill) dan perlindungan (to protect) HAM pasca Orde Baru atau era Reformasi memperlihatkan wajah paradoksal yang tampak dari dua kecenderungan yang seolah saling menihilkan. Di satu sisi, menguat legalisasi norma-norma serta instrumen hak asasi dengan berbagai ratifikasi kovenan hakhak sipil dan politik serta kovenan hak-hak ekonomi, sosial dan budaya, tetapi di sisi lain, pada saat yang sama muncul keresahan akibat meluasnya berbagai bentuk intoleransi terhadap perbedaan-perbedaan, dominasi dan pernyataan kebencian di ruang publik dan media sosial dimana negara lemah memberikan perlindungan terhadap pelbagai bentuk pelanggaran yang terjadi.

Ada kesan bahwa berakhirnya rezim otoritarian dan menguatnya demokrasi sebagai pondasi politik bernegara, berbangsa dan bermasyarakat, keadaan HAM bukan semakin eksis dan memperoleh konteksnya yang tepat untuk penguatan perlindungan, tetapi malah seperti elemen asing demokrasi yang terabaikan. Pelbagai aspek HAM sipil politik seperti antara lain kebebasan beragama kian tereleminir; demokrasi tiba-tiba dibenci dan dicaci maki sambil melupakan bahwa ruang yang dipakai untuk memaki itu adalah buah dari demokrasi.

Hak-hak dan kebebasan sipil (kebebasan beragama) sebagai salah satu elemen demokrasi yang harus terus dipelihara, diperjuangkan dan dijaga bersamaan dengan menjaga dan memperjuangkan demokrasi itu sendiri mulai kepayahan, sekalipun hak-hak hak sipil telah memperoleh status konstitusional yang kuat dalam UUD NRI $1945^{12}$ hasil amandemen dan buah demokrasi hasil perubahan politik. Jaminan konstitusi tersebut merupakan politik hukum (law making) di level konstitusi yang sangat responsif bagi kebutuhan negara hukum dan demokrasi baru. Masalahnya mengapa politik hukum HAM yang kuat dalam jaminan konstitusi demikian itu tidak dengan sendirinya meninggikan toleransi beragama. Yang justru tampak menguat adalah kecenderungan intoleransi terhadap kebebasan beragama.

\section{Rumusan Masalah}

Dari latar belakang di atas, fokus masalah penelitian ini adalah Pertama, bagaimana politik hukum HAM pembuatan peraturan perundang-undangan

\footnotetext{
12 Pasal 28I (1) kebebasan beragama sebagai hak yang tidak bisa dikecualikan dalam keadaan apapun.
} 
sebagai pemenuhan (to fulfill) kebebasan beragama di Indonesia pasca Orde Baru? Kedua, apakah dalam praktik negara makin melindungi (to protect) kebebasan beragama sejalan dengan menguatnya politik hukum pembuatan norma-norma pemenuhan atau justru sebaliknya (gagal melindungi)?

\section{Tujuan Penelitian}

Tujuan penelitian ini yaitu pertama untuk mengkaji politik hukum HAM pembuatan peraturan perundang-undangan sebagai pemenuhan (to fulfill) kebebasan beragama di Indonesia pasca Orde Baru. Kedua, untuk mengkaji praktik negara dalam melindungi (to protect) kebebasan beragama sejalan dengan menguatnya politik hukum pembuatan norma-norma pemenuhan atau justru sebaliknya (gagal melindungi).

\section{Metode Penelitian}

Jenis penelitian ini adalah penelitian hukum yuridis normatif dengan menggali data melalui studi literatur, peraturan perundang-undangan, instrumen internasional, dan dokumen yang berhubungan dengan objek yang diteliti untuk mencari jawaban atas masalah yang diteliti.

Objek dalam penelitian ini adalah politik hukum terhadap kebebasan beragama di Indonesia. Penelitian ini menggunakan teknik pengumpulan bahan hukum yang dilakukan melalui studi pustaka. Pendekatan yang digunakan adalah pendekatan perundang-undangan, (statute approach) dan pendekatan konseptual (conceptual approach). Selanjutnya hasil penelitian dianalisis secara kualitatif, dan dipaparkan dalam bentuk deskriptif analitis.

\section{Hasil Penelitian dan Pembahasan}

\section{Politik Hukum Kebebasan Beragama di Indonesia}

Kebebasan beragama atau berkeyakinan (kebebasan beragama) merupakan salah satu rumpun dalam hak asasi manusia (HAM) sebagaimana termaktub dalam Deklarasi Universal HAM (DUHAM) ${ }^{13}$ dan Kovenan Hak Sipil dan hak

\footnotetext{
13 Pasal 18 Setiap orang berhak atas kebebasan pikiran, hati nurani dan agama; dalam hal ini termasuk kebebasan berganti agama atau kepercayaan, dengan kebebasan untuk menyatakan agama atau kepercayaann dengan cara mengajarkannya, melakukannya, beribadat dan mentaatinya, baik sendiri maupun bersama-sama dengan orang lain, di muka umum maupun sendiri.
} 
Politik. ${ }^{14}$ Hak-hak kebebasan ini telah diakui secara internasional maupun nasional sebagai hak yang tidak bisa dikurangi dan dibatasi dalam keadaan apapun (nonderogable rights). Bahkan dalam keadaan perang dan keadaan darurat umum sekalipun, negara wajib untuk tidak mengintervensi apalagi memaksa (coercion) kebebasan beragama di level forum internum, ${ }^{15}$ sebagaimana diatur dalam Pasal 28I (ayat 1), Pasal 4 (ayat 2) Kovenan Hak Sipil dan Politik dan pasal 74 dan 74 UU HAM. Sementara kebebasan beragama di level forum externum sebagai bentuk kebebasan memanifestasikan agama dapat dibatasi dengan undang-undang. ${ }^{16}$

Politik hukum HAM kebebasan beragama pasca Orde Baru di level internum ${ }^{17}$ dan eksternum ${ }^{18}$ sesungguhnya cukup responsif terhadap kebutuhan pengisian substansi negara hukum dan demokrasi sebagaimana dijamin dalam UUD NRI 1945, UU No. 39 Tahun 1999 Tentang HAM, UU No. 12 Tahun 2005 Tentang ratifikasi Kovenan Hak Sipil Politik.

14 Pasal 18 1. Setiap orang berhak atas kebebasan berpikir, keyakinan dan beragama. Hak ini mencakup kebebasan untuk menetapkan agama atau kepercayaan atas pilihannya sendiri, dan kebebasan, baik secara sendiri maupun bersama-sama dengan orang lain, baik di tempat umum atau tertutup, untuk menjalankan agama dan kepercayaannya dalam kegiatan ibadah, pentaatan, pengamalan, dan pengajaran. 2. Tidak seorang pun dapat dipaksa sehingga terganggu kebebasannya untuk menganut atau menetapkan agama atau kepercayaannya sesuai dengan pilihannya. 3. Kebebasan menjalankan dan menentukan agama atau kepercayaan seseorang hanya dapat dibatasi oleh ketentuan berdasarkan hukum, dan yang diperlukan untuk melindungi keamanan, ketertiban, kesehatan, atau moral masyarakat, atau hak-hak dan kebebasan mendasar orang lain.

${ }^{15}$ Kebebasan internal yang berisi kebebasan hati nurani untuk meyakini, menganut dan berpindah agama dan keyakinan serta hak untuk mempertahankan menganut atau berpindah dari suatu agama atau keyakinan.

16 Pasal 28J (2) UUD 1945. Selain itu dimuat pula dalam Prinsip-Prinsip Siracusa (Siracusa Principles) yang menyebutkan bahwa pembatasan HAM hanya bisa dilakukan jika memenuhi kondisi-kondisi berikut : a. Prescribed by Law (diatur berdasarkan hukum) b. in a democratic society (diperlukan dalam masyarakat demokratis) c. Public Order (untuk melindungi ketertiban umum) d. Public Health (untuk melindungi kesehatan publik) e. Public Morals (untuk melindungi moral publik) f. National Security (untuk melindungi keamanan nasional) g. Public Safety (untuk melindungi keselamatan publik) h. Rights and freedoms of others or the rights or reputations of others (melindungi hak dan kebebasan orang lain)..

17 Pasal 28I (Hak untuk hidup, hak untuk tidak disiksa, hak kemerdekaan pikiran dan hati nurani, hak Beragama...); Pasal 29 (Negara menjamin kemerdekaan tiap-tiap penduduk untuk memeluk agamanya masingmasing dan untuk beribadat menurut agamanya dan kepercayaannya itu); Pasal 4 UU No. 39 Tahun 1999 ("Hak untuk hidup, hak untuk tidak disiksa, hak kebebasan pribadi, pikiran dan hati nurani... adalah hak asasi manusia yang tidak dapat dikurangi dalam keadaan apapun dan oleh siapapun); dan Pasal 22 (1) "(1) Setiap orang bebas memeluk agamanya masing-masing dan untuk beribadah menurut agamanya dan kepercayaanya itu.”

18 Pasal 29 UUD 1945 (“(2) Negara menjamin kemerdekaan tiap-tiap penduduk untuk memeluk agamanya masing-masing dan untuk beribadat menurut agamanya dan kepercayaannya itu); Pasal 22 UU No. 39 Tahun 1999 ((1) Setiap orang bebas memeluk agamanya masing-masing dan untuk beribadah menurut agamnya dan kepercayaanya itu. (2) Negara menjamin kemerdekaan setiap orang memeluk agamanya masing-masing dan untuk beribadat menurut agamanya dan kepercayaanya itu). 
UUD NRI Tahun 1945 Pasal 28E mengatur bahwa "setiap orang bebas"19 memeluk agama dan beribadat menurut agamanya...20. "Setiap orang berhak atas kebebasan meyakini kepercayaan...21. Selanjutnya dalam Pasal $28 \mathrm{I}$ (1) disebutkan: “Hak untuk hidup... hak beragama... adalah hak asasi manusia yang tidak dapat dikurangi dalam keadaan apa pun²2. Selanjutnya Pasal 28I berbunyi: “..., hak beragama ... adalah hak asasi manusia yang tidak dapat dikurangi dalam keadaan apapun". Sementara, Pasal 28J menyatakan: (1) Setiap orang wajib menghormati hak asasi manusia orang lain dalam tertib kehidupan bermasyarakat, berbangsa, dan bernegara. (2) Dalam menjalankan hak dan kebebasannya, setiap orang wajib tunduk kepada pembatasan yang ditetapkan dengan undang-undang dengan maksud semata-mata untuk menjamin pengakuan serta penghormatan atas hak kebebasan orang lain dan untuk memenuhi tuntutan yang adil sesuai dengan pertimbangan moral, nilai-nilai agama, keamanan, dan ketertiban umum dalam suatu masyarakat demokratis. Ditegaskan juga dalam Pasal 29 ayat (2) UUD NRI Tahun 1945, bahwa negara menjamin kemerdekaan tiap-tiap penduduk untuk memeluk agamanya masing-masing dan untuk beribadat menurut agamanya dan kepercayaannya itu.

Pasal 22 UU No. 39 Tahun 1999 menyebutkan bahwa: (1) Setiap orang bebas memeluk agamanya masing-masing dan untuk beribadat menurut agamanya dan kepercayaannya itu; (2) negara menjamin kemerdekaan setiap orang memeluk agamanya masing-masing dan untuk beribadat menurut agamanya dan kepercayaannya itu. Jaminan tentang kebebasan beragama juga dimuat dalam Pasal 18 ayat (1) UU No. 12 Tahun 2005 tentang Ratifikasi Kovenan Internasional Tentang Hak-Hak Sipil dan Politik. Di sana disebutkan bahwa “Setiap orang berhak atas kebebasan berpikir, berkeyakinan dan beragama. Hak ini mencakup kebebasan untuk menganut atau menerima suatu agama atau kepercayaan atas pilihannya

${ }^{19}$ Pada beberapa regulasi di Indonesia, kata freedom umumnya diterjemahkan dengan "kebebasan". Misalnya, terjemahan Pasal 18 ayat (1) ICCPR dalam UU Nomor 12 Tahun 2005 tentang Kovenan Internasional tentang Hak-Hak Sipil dan Politik. Sementara UUD 1945 menggunakan dua kata yaitu "kemerdekaan" dan "kebebasan". Pasal 28E ayat 2 (kebebasan); Pasal 28I ayat (1) (merdeka) ayat (2) (bebas), atau Pasal 29 ayat (2) (merdeka). Dengan redaksi nyaris serupa, kata "kemerdekaan" dalam Pasal 28 I UUD 1945 diubah menjadi "kebebasan" di Pasal 4 UU HAM Nomor 39 Tahun 1999 tentang Hak Asasi Manusia.

${ }^{20}$ Ayat (1)

21 Ayat (2)

22 Ayat (1) 
sendiri, dan kebebasan, baik secara individu maupun bersama-sama dengan orang lain, dan baik di tempat umum atau tertutup untuk menjalankan agama atau kepercayaannya dalam kegiatan ibadah, ketaatan, pengamalan dan pengajaran. Selanjutnya dalam ayat (2) dinyatakan bahwa tidak seorang pun boleh dipaksa sehingga mengganggu kebebasannya untuk menganut atau menerima suatu agama atau kepercayaannya sesuai dengan pilihannya. ${ }^{23}$

Berdasar regulasi-regulasi di atas, maka secara konstitusional negara telah menetapkan politik hukum kebebasan beragama sebagai bagian dari hak asasi manusia yang harus dijamin, dihormati dan dilindungi baik oleh masyarakat maupun pemerintah dan menjadi tanggung jawab negara untuk mewujudkannya sebagaimana ditetapkan dalam ketentuan Pasal 28I ayat (4) UUD Tahun 1945.24

Inti normatif dari hak kebebasan beragama dan berkeyakinan yang dijamin dalam peraturan perundang-undangan setidaknya meliputi delapan elemen, yaitu $^{25}$ : a) kebebasan internal (forum internum)26; b) kebebasan eksternal (forum eksternum)27; c) tidak ada paksaan (non coersion)28; c) tidak diskriminatif (non diskrimination) ${ }^{29}$; d) hak dari orang tua dan wali30; e) kebebasan lembaga dan status

${ }^{23}$ Sayang sekali Indonesia belum meratifikasi Optional Protocol Kovenan Hak Sipil dan Hak Politik sehingga tidak ada jalan untuk membawa kasus pelanggaran atas kebebasan beragama ke Komite HAM PBB ketika semua upaya domestik sudah dilakukan. Karena itulah, politik hukum pemerintah atas kebebasan beragama sebagai salah satu hak sipil politik masih bersifat setengah hati. Di satu sisi sangat terlambat meratifikasi hak sipil dan politik (2005), dan di sisi lain mengabaikan 2 Optional Protocol yang sangat penting bagi implementasi perlindungan hak. Kedua protokol itu adalah optional protocol yang menyangkut mekanisme pengajuan pemulihan hak secara individual bagi korban pelanggaran HAM, serta $s$ tentang penghapusan pidana mati.

${ }^{24}$ Perlindungan, pemajuan, penegakan, dan pemenuhan hak asasi manusia adalah tanggung jawab negara, terutama pemerintah.

25 Pultoni dkk, Panduan Pemantauan Tindak Pidana Penodaan Agama dan Ujaran Kebencian atas Dasar Agama, ILRC, Jakarta, 2012, hlm. 15-17.

26 Kebebasan pada level ini ingin menegaskan, setiap orang mempunyai hak kebebasan berpikir, berkeyakinan dan beragama. Hak ini mencakup kebebasan untuk menganut atau menetapkan agama atau kepercayaan atas pilihannya sendiri, termasuk untuk berpindah agama atau kepercayaannya.

${ }^{27}$ Kebebasan ini menegaskan, setiap orang memiliki kebebasan, secara individu atau dalam masyarakat, secara publik maupun pribadi, untuk memanifestasikan agama dan kepercayaannya dalam pengajaran, pengamalan dan peribadatannya.

28 Tidak seorang pun dapat dipaksa yang akan mengurangi kebebasannya untuk memiliki atau menganut suatu agama atau kepercayaan yang menjadi pilihannya.

${ }^{29}$ Negara berkewajiban untuk menghormati dan menjamin kebebasan beragama dan berkeyakinan bagi semua individu di dalam wilayah kekuasaannya tanpa membedakan suku, agama, keyakinan, ras, jenis kelamin, bahasa, politik, pendapat dan asalusul.

${ }^{30}$ Negara berkewajiban untuk menghormati kebebasan orang tua dan wali yang sah untuk menjamin bahwa pendidikan agama dan moral bagi anak-anaknya sesuai dengan keyakinannya sendiri, selaras dengan kewajiban untuk melindungi hak atas kebebasan beragama dan berkeyakinan. 
$\operatorname{legal}^{31}$; f) pembatasan yang diijinkan ${ }^{32}$; dan h) tidak dapat dikurangi ${ }^{33}$ (NonDerogable).

Kebebasan seseorang untuk menjalankan agama atau kepercayaannya, hanya dapat dibatasi oleh ketentuan hukum, yang diperlukan untuk melindungi keamanan, ketertiban, kesehatan atau moral masyarakat atau hak dan kebebasan mendasar orang lain (ayat (3). ${ }^{34}$ Tetapi pembatasan yang dimaksudkan dalam Pasal 28J serta Kovenan Hak Sipil dan Politik Pasal 18 (3) adalah wilayah 'menjalankan' atau manifestasi dari hak dan kebebasan beragama dan berkeyakinan (forum externum), 35 dan tidak pada wilayah forum internum (non derogable right) karena forum internum adalah wilayah tempat beradanya pengakuan batin personal seorang individu. ${ }^{36}$ Di sinilah tempat beradanya keyakinan spiritual individual yang secara persis hanya diketahui oleh sang empunya sendiri.

Wilayah internum tidak dapat diintervensi oleh individu lain atau entitas lain yang berada di luar diri pemilik forum, karena dimensi inilah substansi kebebasan individu untuk memilih agama atau keyakinannya, dan untuk menganutnya di dalam lingkup privat. ${ }^{37}$ Termasuk dalam aspek internum ini adalah hak untuk berganti agama jika pada saatnya individu bersangkutan merasa perlu mengganti agama dan keyakinannya tersebut. Bahkan, Pasal 18 Kovenan Hak Sipil Politik menjamin hak individu untuk tidak mempunyai satu agama yang diyakininya. ${ }^{38}$

31 Aspek yang vital dari kebebasan beragama dan berkeyakinan, bagi komunitas keagamaan untuk berorganisasi atau berserikat sebagai komunitas. Oleh karena itu, komunitas keagamaan memiliki kebebasan dalam beragama dan berkeyakinan, termasuk di dalamnya hak kemandirian dalam mengatur organisasinya.

32 Kebebasan untuk memanifestasikan agama dan keyakinan hanya dapat dibatasi oleh undang-undang dan kepentingan melindungi keselamatan dan ketertiban publik, kesehatan atau kesusilaan umum dan hak-hak dasar orang lain.

${ }^{33}$ Negara tidak boleh mengurangi kebebasan beragama dan berkeyakinan dalam keadaan apapun.

34 Pembatasan melalui peraturan perundang-undangan adalah norma publik yang memungkinkan publik (orang banyak) berpartisipasi dalam membentuk dan mengawasi pelaksanaannya, yang dilakukan dengan tetap memenuhi asas keperluan (necessity) dan proporsionalitas.

35 Natan lerner, Sifat dan Standar Minimun Kebebasan Beragama atau Berkeyakinan, Kebebasan Beragama dan Berkeyakinan Seberapa Jaub?, Kanisius, Yoyakarta, 2010, hlm. 176-178.

${ }^{36}$ Lihat Rusman Widodo, "Editorial”, dalam Jurnal HAM, Komnas HAM, Jakarta, Volume VI Tahun 2010, hlm ix. Lihat juga Alasan berbeda (concurring opinion) Hakim Konstitusi Harjono pada putusan MK No. 140/PUUVII/2009. Dapat diunduh melalui www.mahkamahkonstitusi.go.id

${ }^{37}$ Lihat komentar Umum Nomor 22 tentang Pasal 18 ICCPR. Edisi bahasa Indonesia komentar umum ini dapat dilihat dalam Komnas HAM, Komentar Umum Kovenan Internasional Hak Sipil Politik Hak Ekonomi, Sosial dan Budaya, Komnas HAM, Jakarta, 2009, hlm. 50-53.

${ }^{38}$ Ketentuan ini untuk konteks Indonesia tidak berlaku karena ada kewajiban bagi setiap warga negara mencantumkan agama yang dianut sebagai salah identitas sebagai warga negara. Baca UU No. 23 Tahun 2006 tentang Administrasi Kependudukan; UU No. 1 Tahun 1974 tentang Perkawinan (perkawinan hanya sah bila dilakukan menurut hukum dari masing-masing agama yang dianutnya). 
Forum internum tidak hanya menjamin perlindungan terhadap hak untuk memilih dan memiliki agama atau keyakinan, melainkan juga pelaksanaanya dalam ruang privat. Sedangkan pelaksanaan pada ruang publik, sekali lagi, sebagaimana pada forum eksternum dapat dibatasi. Tetapi pembatasan dimaksud harus sejalan dengan rambu-rambu yang yang digariskan dalam Kovenan Hak Sipil dan Politik. ${ }^{39}$

Bagian lain dari politik hukum pemerintah adalah dikeluarkannya Peraturan Presiden (Perpres) No. 7 Tahun 2005 tentang Rencana Pembangunan Jangka Menengah Nasional 2004-2009 yang di dalamnya diatur tentang peningkatan kerukunan intern dan antarumat beragama sebagai salah satu dari arah kebijakan pembangunan kehidupan beragama. Fokus dari Perpres tersebut: Pertama, memberdayakan masyarakat, kelompok-kelompok agama, serta pemuka agama untuk menyelesaikan sendiri masalah kerukunan umat beragama (KUB); dan Kedua, memberikan rambu-rambu dalam pengelolaan kerukunan umat beragama.

Forum Kerukunan Umat Beragama (FKUB) dibentuk di 306 kabupaten/ kota dan di seluruh provinsi di Indonesia dalam rangka pemberdayaan masyarakat. Sementara terkait rambu-rambu pengelolaan kerukunan umat beragama, pemerintah telah menerbitkan berbagai peraturan perundang-undangan yang mengatur hubungan antar-umat beragama, baik yang berhubungan dengan hak dan kebebasan beragama, penyebarluasan ajaran agama, dan interaksi sosial di antara mereka, antara lain Peraturan Bersama (PBM) Menteri Agama dan Menteri Dalam Negeri No. 9 dan 8 Tahun 2006 tentang Pedoman Pelaksanaan Tugas Kepala Daerah/Wakil Kepala Daerah Dalam Pemeliharaan Kerukunan Umat Beragama, Pemberdayaan Forum Umat beragama, dan Pendirian Rumah Ibadat, atau dikenal dengan Forum Kerukunan Umat Beragama (FKUB).

\footnotetext{
${ }^{39}$ Paragraf 8 Komentar Umum No. 22 (General Comment No. 22) atas Pasal 18 ayat (3) Kovenan Hak Sipil dan Politik yang memuat: (a) Diatur oleh hukum, dan perlu untuk melindungi keamanan masyarakat, ketertiban umum, kesehatan atau moral, atau hak dan kebebasan orang lain yang fundamental; (b) Pembatasan harus dihubungkan dan proporsional dengan kebutuhan yang spesifik; (c) Pembatasan tidak boleh dengan maksud dan cara-cara yang diskriminatif; (d) Pembatasan atas dasar melindungi moral tidak boleh didasarkan secara eklusif atas dasar moral tunggal; (e) Pembatasan akan permissible ${ }^{39}$ apabila didasarkan hukum yang tidak diskriminatif (Pasal 2, 3 dan 26 Kovenan Hak Sipol), dan tidak menegasikan hak-hak yang diakui oleh Pasal 18 Kovenan Hak Sipol, dan (f) Pembatasan yang ada di dalam Pasal 18 ayat (3) harus ditafsirkan secara sensu stricto (terbatas).
} 
Konsideran menimbang, ${ }^{40}$ PBM menyebutkan bahwa hak beragama adalah hak asasi manusia yang tidak dapat dikurangi dalam keadaan apapun; setiap orang bebas memilih agama dan beribadat menurut agamanya; negara menjamin kemerdekaan tiap-tiap penduduk untuk memeluk agamanya masing-masing dan untuk beribadat menurut agamanya dan kepercayaannya itu; Pemerintah berkewajiban melindungi setiap usaha penduduk melaksanakan ajaran agama dan ibadat pemeluk-pemeluknya, sepanjang tidak bertentangan dengan peraturan perundang-undangan, tidak menyalahgunakan atau menodai agama, serta tidak mengganggu ketenteraman dan ketertiban umum; Pemerintah mempunyai tugas untuk memberikan bimbingan dan pelayanan agar setiap penduduk dalam melaksanakan ajaran agamanya dapat berlangsung dengan rukun, lancar, dan tertib; arah kebijakan Pemerintah dalam pembangunan nasional di bidang agama antara lain peningkatan kualitas pelayanan dan pemahaman agama, kehidupan beragama, serta peningkatan kerukunan intern dan antar umat beragama.

Kerukunan umat beragama yang dimaksud PBM adalah keadaan hubungan sesama umat beragama yang dilandasi toleransi, saling pengertian, saling menghormati, menghargai kesetaraan dalam pengamalan ajaran agamanya dan kerjasama dalam kehidupan bermasyarakat, berbangsa dan bernegara di dalam Negara Kesatuan Republik Indonesia berdasarkan Pancasila dan Undang-Undang Dasar NRI Tahun 1945.41 Sedangkan pemeliharaan kerukunan umat beragama adalah upaya bersama umat beragama dan Pemerintah di bidang pelayanan, pengaturan, dan pemberdayaan umat beragama. ${ }^{42}$

Tugas yang diemban FKUB meliputi: melakukan dialog dengan pemuka agama dan tokoh masyarakat, menampung aspirasi ormas keagamaan dan masyarakat, menyalurkan aspirasi ormas keagamaan dan masyarakat dalam bentuk rekomendasi sebagai bahan kebijakan kepala pemerintahan, melakukan sosialisasi peraturan perundang-undangan dan kebijakan di bidang keagamaan yang berkaitan dengan kerukunan umat beragama dan pemberdayaan

40 Muatan konsideran menimbang dalam peraturan bersama tersebut memuat merupakan aspek filosofis dan yuridis yang mendasari lahirnya substansi peraturan (Perba).

${ }^{41}$ Ketentuan Umum Pasal 1 (1).

42 Ibid, Pasal 1 (2). 
masyarakat, dan memberikan rekomendasi tertulis atas permohonan pendirian rumah ibadat bagi FKUB tingkat kota/kabupaten.

Reaksi yang timbul akibat lahirnya FKUB cukup beragam, antara lain: Pertama, menerima kehadiran FKUB sebagai wadah atau forum yang secara khusus mengurusi kehidupan antarumat beragama. Kedua, menerima keberadaan FKUB dengan syarat dilebur dengan wadah yang sudah ada sebelumnya. Ketiga, menolak kehadiran FKUB karena khawatir menjadi alat intervensi pemerintah. Akibatnya kinerja FKUB menjadi kurang maksimal.43

Terkait dengan PBM No. 8 dan 9 Tahun 2006 sebagai pedoman pelaksanaan tugas kepala daerah/wakil kepala daerah dalam pemeliharaan kerukunan umat beragama, pemberdayaan forum kerukunan umat beragama dan pendirian rumah ibadat memang terdapat beberapa masalah yang secara langsung atau tidak langsung menjadi titik lemah PBM. Evaluasi PBM yang dilakukan oleh The Indonesian Institute pada 2015 menyebutkan adanya 4 kelemahan, yaitu: ${ }^{44}$ Pertama, ketidaksepemahaman pemerintah daerah dan pengurus FKUB tentang PBM 2006. Kedua, pembentukkan FKUB dianggap hanya sekedar formalitas. Ketiga, rekruitmen anggota FKUB yang didasarkan perbandingan jumlah pemeluk agama memungkinkan terjadinya dominasi mayoritas. Keempat, tidak jelasnya program kerja dan kegiatan FKUB yang lebih banyak melakukan kunjungan/ studi ke luar negeri dan ke daerah-daerah, sehingga tidak menjawab masalah-masalah yang ada di daerah itu sendiri.

The Indonesian Institute 45 juga melansir kelemahan lain, yaitu: Pertama, lemahnya peran aktor dalam melaksanakan peraturan tersebut dimana pemerintah pusat dan daerah dianggap tidak memiliki political will dalam menjalankan PBM 2006. Kedua, lemahnya sosialisasi PBM 2006 yang menimbulkan ketidaksepemahaman di antara pemerintah pusat dan pemerintah daerah mengenai subtansi PBM 2006; tugas dan kewenangan kepala daerah; peran dan pemberdayaan FKUB; pelaksanaan syarat pendirian rumah ibadah hingga penyelesaian konflik yang ditimbulkan dari pendirian rumah ibadah. Ketiga,

43 Muhammad Anang Firdaus, "Eksistensi FKUB dalam Memelihara Kerukunan Umat Beragama di Indonesia", Kontekstualita, Vol. 29, No.1, 2014, hlm. 71.

${ }^{44}$ The Indonesian Institute, Policy Brief, Maret 2015.

${ }^{45}$ Ibid. 
lemahnya penegakan hukum, karena PBM 2006 tidak memiliki kekuatan hukum mengikat serta tidak adanya sikap tegas kepala daerah untuk menegakkan hukum. Keempat, lemahnya pendidikan multikultural di masyarakat, dan lemahnya pengetahuan tentang perbandingan agama-agama, sehingga masyarakat kita tidak saling mengenal antar agama yang berakibat munculnya fanatisme buta di sebagian masyarakat yang mengancam kebhinekaan bangsa.

Khusus terkait pendirian rumah ibadah, PBM juga gagal menjadi instrumen hukum yang efektif. Dalam beberapa kasus, izin pendirian rumah ibadah pada kenyataannya tidak mudah karena acapkali menyulut konflik antar umat beragama. Pembangunan (dari yang tidak ada menjadi ada) atau renovasi (perbaikan dari yang sudah ada) tempat atau rumah ibadah adalah salah satu persoalan yang cukup menonjol dalam dinamika kehidupan kebebasan beragama. 46

Penolakan pendirian rumah ibadah dapat dikelompokkan dalam tiga faktor; pertama, faktor aturan sebagaimana termaktub dalam PBM No. 9 dan 8 Tahun 2006 Bab IV tentang pendirian rumah ibadat pasal $14 .{ }^{47} \mathrm{Kedua}$, faktor sentimen agama, yaitu ketidaksiapan atas munculnya dan perkembangan rumah ibadat lain ${ }^{48}$, dan ketiga adalah faktor sosial politik ${ }^{49}$. Meskipun pengaturan rumah ibadat bukanlah intervensi pemerintah atau negara terhadap agama, melainkan bersifat administratif saja, tetapi persyaratan pendirian rumah ibadat yang diatur dalam Pasal 14 PBM No. 9 dan 8 Tahun 2006 yang mensyaratkan jumlah pengguna dan

46Pelarangan Pembangunan Masjid Batuplat di Kupang NTT,pelarangan Pembangunan Mushalla As Syafi iyah Kota Denpasar,penghentian Aktivitas 19 Gereja di Aceh Singkil,Penyegelan 7 Gereja di Banda Aceh,Penghe ntian Pembangunan Gereja di Kota Bandung,Penyegelan 7 Gereja di Cianjur,Penghentian Pembangunan Masjid di Manokwari,Penyegelan Gereja GKI Yasmin Bogor,Pelarangan 7 Gereja DI Kabupaten Bandung,

Pembongkaran dan Perusakan HKI Samarinda, Pelarangan Pendirian Masjid di Bitung. (Baca Laporan Akhir Tahun Pelapor Khusus Kebebasan Beragama Dan Berkeyakinan Komnas HAM, Tahun 2015, hlm. 10-15).

47 Aturan tersebut meliputi: persyaratan administratif dan teknis pendirian rumah ibadat. Persyaratan khusus pendirian rumah ibadat berupa; daftar nama dan kartu tanda penduduk pengguna rumah ibadat paling sedikit 90 (sembilan puluh) orang yang disahkan oleh pejabat setempat sesuai dengan tingkat batas wilayah dan dukungan masyarakat setempat paling sedikit 60 (enam puluh) orang yang disahkan oleh lurah/kepala desa, serta adanya rekomendasi tertulis kepala Kantor Departemen Agama Kabupaten/Kota dan FKUB. Jika persyaratan tersebut di atas tidak terpenuhi, maka pemerintah daerah berkewajiban memfasilitasi tersedianya lokasi pembangunan rumah ibadat. keagamaan.

${ }_{48}$ Kekhawatiran akan pemurtadan (konversi agama) dan takut persaingan antar aliran atau paham

${ }^{49}$ Kekhawatiran akan cepatnya pertumbuhan penganut agama lain yang dapat merubah peta komposisi penduduk agama lain, persaingan peranan sosial dan pengusaan ekonomi. Solusi yang ditawarkan adalah pemerintah daerah menerbitkan Pergub/Perbup/Perwali, sosialisasi PBM dan pendekatan antarwarga beda agama melalui komunikasi sosial-budaya. 
keharusan adaya dukungan dari masyarakat setempat menjadi sulit untuk dipenuhi oleh penganut agama yang jumlahnya minoritas di suatu daerah, padahal mereka juga berhak untuk memperoleh jaminan dalam menjalankan keyakinan dan ajaran agamanya dengan aman dan nyaman.

Berdasarkan uraian di atas, dapat ditegaskan bahwa politik hukum HAM pemenuhan (to fulfill) kebebasan beragama di Indonesia pasca Orde Baru menunjukkan perbaikan signifikan melalui penegasan kedudukan konstitusional kebebasan beragama dalam UUD NRI 1945, dalam UU No. 39 Tahun 1999, dan pelbagai peraturan perundang-undangan lainnya Regulasi lain yang terkait kebebasan beragama seperti UU No. No. 23 Tahun 2006 tentang Administrasi Kependudukan50; UU No. 20 Tahun 2003 tentang Pendidikan Nasional51; dan UU No. 23 Tahun 2002 tentang Perlindungan Anak ${ }^{52}$, serta regulasi pendirian rumah ibadah dan kerangka hukum bagi penciptaan kerukunan antar umat beragama. Tetapi penguatan di tingkat pemenuhan (to fulfill) tidak dengan sendirinya (dalam realitas) menghadirkan perlindungan (to protect) terhadap kebebesan menjalankannya. ${ }^{3}$

\section{Realitas Kebebasan Beragama Pasca Orde baru}

Sebagaimana telah diuraikan di muka, politik hukum HAM kebebasan beragama di Indonesia menampilkan wajah paradoksal. Di satu sisi jaminan

${ }^{50}$ Dalam UU disebut bahwa individu dengan agama dan keyakinan yang berbeda akan diakui dan memiliki KTP jika agama dan keyakinan individu dimaksud masuk katagori organisasi.

${ }^{51}$ Dalam Pasal 30, 36 dan 37 UU ini disebutkan yang menegaskan setiap berhak mendapatkan pendidikan agama dan beribadah menurut agamanya, berpikir, dan berekspresi sesuai dengan tingkat kecerdasan dan usianya, dalam bimbingan orang tua.

52 Pasal 6 (d) berbunyi: Yang berhak menunaikan ibadah sesuai dengan ajaran agamanya; Pasal 19 (3 dan 4): dalam hal pengasuhan anak dilakukan oleh lembaga yang tidak berlandaskan agama, maka pelaksanaan pengasuhan anak harus memperhatikan agama yang dianut anak yang bersangkutan; Pasal 39 (3) Dalam hal pengangkatan anak, calon orang tua angkat harus seagama dengan agama yang dianut oleh calon anak angkat; dan Pasal 39 (4) Setiap anak mendapat perlindungan untuk beribadah menurut agamanya.

${ }^{53}$ Harus diakui bahwa penguatan politik hukum pemenuhan berupa lahirnya pelbagai peraturan perundangundangan tidak otomatis mengatasi masalah karena di dalam setiap peratran perundang-undangan tersimpan masalah tersendiri satu diantaranya ambuguitas pasal. Kedua, terdapat pertentangan diantara peraturan perundangundangan. Selain itu mengutip M. Amin Abdullah Jaminan normatif terhadap hak KBB pada praktek di Indonesia masih dilingkupi berbagai tiga masalah yang saling berkaitan satu sama lain, yaitu Pertama, permasalahan perundangundangan; kedua, peran aparat negara dalam penegakan hukum; dan ketiga, pemahaman tentang negara-bangsa (nation-states) oleh masyarakat atau warga negara penganut agama-agama, pemangku adat dan anggota ras atau etnis. Baca M. Amin Abdullah, "Kebebasan Beragama atau Berkeyakinan Dalam Perspektif Kemanusiaan Universal, Agama-agama dan Keindonesiaan”, makalah, disampikan pada Training HAM Lanjutan Untuk Dosen Hukum dan HAM, kerjasama Pusat Studi HAM Universitas Islam Indonesia dan Norwegian Centre For Human rigth, Yogyakarta: 810 Juni 2011, hlm 16 
hukum kebebasan beragama menguat, tetapi di sisi lain meninggi pula sikap intoleransi beragama serta lemahnya negara dalam memberikan perlindungan terhadap kebebasan beragama tersebut. Dalam bahasa Hasyim Asy'ari, perkembangan politik hukum kebebasan beragama di Indonesia berjalan tidak linear, namun penuh dinamika sebagaimana pengalaman historis relasi antara negara dan agama yang terjadi selama ini karena dipengaruhi pandangan (persepsi/pemahaman) antara negara dengan masyarakat dan antar warga masyarakat. 54

Politik hukum penguatan landasan hukum kebebasan beragama di tingkat Konstitusi, UU No. 39 Tahun 1999, dan UU No. 12 Tahun 2005 tidak diikuti dengan perbaikan atau perubahan peraturan perundang-undangan lain yang terkait dengan kebebasan beragama, terutama UU PNPS No. 1 tahun $1965^{55}$ dan Pasal 156a KUHP masih berlaku dan dipergunakan oleh kekuatan mayoritas agama untuk menekan negara yang lemah guna mempidanakan setiap orang yang dianggap oleh kekuatan mayoritas tersebut telah menodai agama tertentu. Pada kasus-kasus pidana dengan menggunakan ketentuan Pasal 156a KUHP, umumnya para terdakwa dijerat dengan tuduhan penghinaan agama, penghinaan nabi, atau membuat penafsiran atau ajaran menyimpang.

Kasus-kasus yang terjadi, ${ }^{56}$ semuanya selalu didahului oleh tekanan dari massa mayoritas yang mendominasi dan menghegemoni tafsir atas suatu agamadan bukan didahului oleh inisiatif aparat penegak hukum yang memandang perbedaan a quo sebagai suatu penodaan sehingga klaim penodaan agama bukanlah masalah hakikat dari kebenaran itu sendiri, tetapi lebih karena tekanan massa. Tekanan massa mayoritas yang menilai kepercayaan atau keyakinannya dinodai tanpa mengerti secara mendalam substansi masalah yang disebut sebagai

\footnotetext{
${ }^{54}$ Hasyim Asy'ari, "Politik Hukum Kebebasan Beragama di Indonesia”, dalam Jurnal Hukum Pandecta, Vol. 6, No. 1, Januari 2011, Fakultas Hukum Universitas Diponegoro, Semarang, 2011, hlm. 1-14.

${ }^{55}$ UU ini sudah diuji untuk minta dibatalkan oleh para pemohon dari kalangan LSM dan sejumlah tokoh karena para pemohon menilai PNPS bertentangan dengan Pasal 1 (3), Pasal 27 (1), Pasal 28D (1), Pasal 28E (1,2, 3), Pasal 28I (1,2) dan Pasal 29 (2) UUD 1945 tetapi permohonan itu ditolak oleh MK.

56 Sepanjang tahun 2005 hingga 2017 saja sejumlah orang telah didakwa dengan Pasal 156a, yaitu: Lia Aminuddin alias Lia Eden; Ardi Husain (Pengurus Yayasan Kanker dan Narkoba Cahaya Alam); Sumardin Tapayya/Shalat bersiul; Yusman Roy/Shalat Dwi Bahasa; Mangapin Sibuea (pendeta pemimpin sekte kiamat ${ }^{\circledR}$ pada Pondok Nabi di daerah Baleendah, Bandung); Ahmad Mushaddeq yang mengaku Rasul baru yang bergelar AlMasih Al-Ma’ud; dan terakhir Basuki Tjahaja Purnama (Ahok).
} 
tindakan atau perkataan menodai itu, lalu memaksa negara melakukan tindakan hukum menggunakan peraturan perundang-undangan lebih rendah yang berlawanan dengan jaminan hukum yang lebih tinggi (UUD 1945).

Contoh-contoh kasus perkara penodaan agama di atas yang menggunakan UU PNPS No. 1 Tahun 1965 dan Pasal 156a KUHP membuktikan lemahnya politik hukum perlindungan HAM kebebasan beragama di Indonesia,57 baik karena inkonsistensi dan ketidakpatuhan negara terhadap asas-asas hukum dengan menggunakan UU lebih rendah bertentangan dengan UU yang lebih tinggi maupun lemahnya negara melindungi kebebasan beragama dari tekanan massa yang memaksa ditegakkannya hukum terhadap individu dan/atau kelompok yang divonis oleh massa sebagai menghina atau menistakan agama.

Pembiaraan terhadap pelanggaran kebebasan individu untuk menganut dan memilih agama dan kepercayaannya berimplikasi pada terlanggarnya hak atas pendidikan, kesehatan, pekerjaan, dan akses layanan publik, misalnya meminta individu untuk mengurungkan niatnya sekolah di salah satu sekolah negeri dengan alasan tidak diajarkannya materi pelajaran agama sebagaimana dianut individu bersangkutan sudah merupakan pemaksaan secara tidak langsung (indirect coercion). 58

${ }^{57}$ UU PNPS No. 1 Tahun 1965 pernah diuji di MK 2010. Dalam putusannya Nomor: 140/PUU-VII/2009 tanggal 19 April 2010, menyatakan menolak semua permohonan pemohon dalam sidang uji materil UU No.1/PNPS/1965 tentang Pencegahan Penyalahgunaan dan/atau Penodaan Agama. MK mengakui bahwa UU No.1/PNPS/1965 memerlukan penyempurnaan, bahkan sebuah undang-undang baru pun mungkin perlu dibuat untuk mengakomodasi substansi undang-undang itu, untuk menjamin perlindungan dan kebebasan beragama. Tetapi sampai undang-undang baru seperti itu disahkan, maka UU No. 1/PNPS/1965 jo. UU No.5 Tahun 1969 tidak perlu dicabut karena akan menyebabkan kevakuman hukum. MK juga berpendapat bahwa undang-undang itu masih berada dalam koridor UUD 1945 dan masih dalam koridor dokumen-dokumen internasional tentang Hak Asasi Manusia. MK juga berargumen bahwa negara memang tidak boleh mencampuri urusan doktrin agama, tetapi negara justeru harus mengambil langkah-langkah yang diperlukan untuk menjamin kebebasan dan kerukunan beragama. Bahkan negara juga dapat melakukan pembatasan-pembatasan yang tidak dengan sendirinya berarti mendiskriminasi melainkan untuk menjamin hak-hak orang lain. Selain itu, MK juga memberikan rambu-rambu tentang bagaimana cara membaca pasal-pasal tertentu dan ungkapan-ungkapan tertentu yang termuat dalam undang-undang tersebut.

58 Dalam laporan tahunan kemerdekaan beragama/berkeyakinan di Indonesia The Wabid Institute tahun 2015, hlm. 18-20 menyebutkan bentuk-bentuk pelanggaran terhadap kebebasan beragama antara lain : 1. Pemaksaan dengan intimidasi atau ancaman fisik, Tindakan ini merupakan tindakan aparat negara seperti polisi, tentara, atau Satpol PP yang melakukan ancaman penggunaan fisik atas dasar agama terhadap seserang atau kelompok penganut agama atau kepercayaan; 2. Pemaksaan ancaman sanksi bukum, Tindakan ini merupakan tindakan aparat negara yang mengancam atas nama agama seseorang atau penganut suatu agama atau kepercayaan dengan ancaman sanksi hukum seperti penjara, denda, tidak menerima KTP atau bentuk-bentuk administrasi lainnya; 3. Kriminalisasi keyakinan, berupa tindakan penerapan sanksi dalam peraturan undangan, umumnya tentang penyalahgunaan dan penodaan agama. Tindakan dapat berbentuk penyelidikan, penyidikan, pemidanaan, penuntutan ke pengadilan hingga pemenjaraan terhadap seorang atau sekelompok orang yang divonis melakukan penodaan terhadap suatu agama di Indonesia. 4. Pemaksaan dengan kebijakan. Tindakan ini merupakan praktik aparat negara yang menerapkan 
Bagian lain yang terkait dengan pelaksanaan Peraturan Bersama Menteri Agama dan Menteri Dalam Negeri tentang Pedoman Pelaksanaan Tugas Kepala Daerah/Wakil Kepala Daerah dalam Pemeliharaan Kerukunan Umat Beragama, Pemberdayaan Forum Kerukunan Umat Beragama, dan Pendirian Rumah Ibadat menunjukkan rendahnya respon pemerintah daerah. Bahkan pelanggaran justru dilakukan oleh pemerintah daerah (Pemda) yang cenderung melokalisir atau menyederhanakan persoalan atau bahkan menutupi kenyataan dengan mengatakan bahwa tidak ada pelanggaran hak atas Kebebasan Beragama dan Berkeyakinan (KBB) di wilayahnya, dan meminta Komnas HAM tidak mencari-cari masalah. Pemda memandang hak atas KBB sebagai masalah kecil dan sederhana, dengan membandingkannya dengan praktik-praktik yang baik,, 59 dan karena itu meminta semua pihak tidak terlalu dibesar-besarkan. ${ }^{60}$ Pemda menilai, keterlibatan Komnas HAM dalam penyelesaian masalah justru akan membuat masalah yang kecil menjadi masalah nasional bahkan internasional. ${ }^{61}$

Hambatan lainnya adalah kecenderungan Pemerintah Daerah untuk mengintervensi masalah agama dengan alasan menjaga ketertiban masyarakat

sanksi hukum atau kebijakan tertentu seperti tidak mengeluarkan kartu identitas atau tidak mencatat akta perkawinan karena seseorang bagian dari sekte tertentu seperti Ahmadiyah, misalnya.5. Pembatasan ibadah, tindakan aparat negara yang berusaha membatasi atau menghalangi seseorang atau sekelompok orang untuk beribadah baik di rumah ibadah atau tempat ibadah tertentu. 6. Pelarangan Ibadah merupakan tindakan aparat negara yang melarang seseorang atau sekelompok orang, melalui surat resmi pelarangan maupun tindakan melarang beribadah. 7. Pembiaran, merupakan tindakan pengabaian atau kelalaian negara mencegah pelanggaran atau intoleransi yang dilakukan oleh warga negara atas dasar agama. Tindakan ini dapat berbentuk tidak mencegah kekerasan yang belum terjadi, tidak melakukan upaya yang sesuai prosedur hukum untuk menghentikan kekerasan terhadap kelompok keagamaan oleh kelompok agama lain, dan tidak mengambil tindakan hukum yang semestinya terhadap para pelaku kekerasan atas nama agama, baik secara individu maupun kelompok. Dalam tindakan pembiaran ini, aparat negara biasanya berdalih bahwa mereka tidak mampu mencegah atau menghentikan kekerasan karena minimnya personel, atau dalih untuk menghindari konflik yang lebih besar. Aparat negara sebaliknya mengevakuasi korban kekerasan dengan dalih untuk mengamankan mereka, atau meminta korban pindah ke tempat lain agar tidak menjadi korban kekerasan berikutnya.8. Pembatasan aktivitas keagamaan, tindakan aparat negara yang berusaha membatasi atau menghalangi seseorang atau sekelompok orang untuk melakukan aktivitas keagamaan seperti pemilihan pimpinan agama, penyebaran ajaran keagamaan, dan lain-lain. 9. Pelarangan aktivitas keagamaan, berupa larangan aparat negara, resmi maupun kebijakan saat di lapangan terhadap aktivitas keagamaan tertentu. 10. Penyegelan tempat ibadah merupakan tindakan pencabutan izin, pelarangan penggunaan bangunan sebagai tempat ibadah, dan berbagai tindakan lain yang bertujuan agar suatu rumah ibadah tidak berdiri di satu lokasi.

59 Dalam kasus pelarangan Mushalla di Denpasar dan pelarangan gereja di Banda Aceh misalnya, Pemerintah setempat menilai pelanggaran hak atas KBB yang terjadi tidak sebanding dengan prestasi Pemerintah dalam menjamin hak beragama, menghormati perbedaan dan menjaga kerukunan. Oleh karena itu, Pemerintah menganggap masalah yang ada tidak perlu dibawa secara nasional dan cukup diselesaikan dengan mekanisme lokal (Baca Laporan akhir tahun pelapor khusus kebebasan beragama dan berkeyakinan Komnas HAM 2015, hlm. 11-13

${ }^{60}$ Laporan Akhir Tahun Pelapor Khusus Kebebasan Beragama dan Berkeyakinan Komsi Nasional Hak Asasi Manusia, Komnas HAM, Tahun 2015, hlm. 25-27

$$
61 \text { Ibid. }
$$


serta mencegah konflik. Bentuk intervensi tersebut bukan dengan menjamin setiap warga memperoleh hak atas KBB-nya, melainkan membatasi kelompok minoritas demi mengikuti selera mayoritas. ${ }^{62}$ Surat edaran pelarangan Asyura misalnya, Walikota Bogor beralasan bukan untuk mencampuri urusan akidah umat Syiah, melainkan untuk mencegah konflik di masyarakat. Begitu pula tindakan Bupati Aceh Singkil yang membuat kesepakatan dengan kelompok yang menolak keberadaan gereja di Aceh Singkil bukan untuk melanggar hak atas KBB warga Kristen di sana, melainkan untuk mencegah konflik dan menciptakan ketetiban masyarakat. ${ }^{63}$ Kuatnya intervensi Pemerintah Daerah ${ }^{64}$ terhadap urusan agama ini, seiring pula dengan rendahnya respons dari Pemerintah Pusat yang cenderung membiarkan Pemerintah Daerah melaksanakan kewenangan yang sebenarnya bertentangan dengan undang-undang. ${ }^{65}$

Hampir semua kasus KBB yang ditangani Komnas HAM ${ }^{66}$ pada 2016 ini, terdapat kecenderungan kebijakan-kebijakan daerah dan penegakan hukum yang lebih tajam kepada kelompok minoritas dan longgar terhadap kelompok mayoritas. Dalam kasus-kasus pembatasan atau pelarangan pendirian rumah ibadah, tindakan pembatasan lebih banyak ditujukan kepada rumah-rumah ibadah kelompok minoritas. Mereka misalnya diharuskan memenuhi semua ketentuan persyaratan pendirian rumah ibadah. Padahal bila diteliti secara seksama, rumahrumah ibadah yang didirikan kelompok mayoritas sebagian besar tidak memenuhi ketentuan pendirian rumah ibadah, yang diakui oleh beberapa pejabat Pemerintah Daerah, tetapi berjalan terus karena tidak ada yang mempersoalkan. ${ }^{67}$

Dalam kasus pelaksanaan hari raya keagamaan kelompok minoritas di satu daerah misalnya, Komnas HAM menemukan polisi justeru mendesak kelompok minoritas untuk tunduk pada kehendak mayoritas demi terciptanya kondusivitas dan ketertiban wilayah. ${ }^{68}$ Pada bagian lain, penanganan kasus juga lamban dan

62 Ibid

63 Ibid

${ }^{64}$ Komnas HAM melansir temuan bahwa pemerintah Daerah (Provinsi/ Kabupaten / Kota) paling banyak diadukan sebagai pelaku pelanggaran hak atas KBB dengan 52 pengaduan. Jumlah ini meningkat drastis dari tahun 2015 yang berjumlah 36 pengaduan (Baca Laporan tahunan Kebebasan Beragama dan Berkeyakinan, Komnas HAM, Tahun 2016, hlm. 104-105
65 Ibid
66 Ibid
${ }^{67}$ Ibid., hlm. 107
68 Ibid 
cenderung dibiarkan seperti pengungsi Ahmadiyah di Mataram NTB dan pengungsi Syiah di Sidoarjo Jawa Timur. Dengan demikian menjadi jelas bahwa politik hukum HAM negara dalam rangka memenuhi dan menjamin kebebasan beragama selain harus diwujudkan dalam bentuk regulasi yang kuat, konsisten, harmonis dan sinkron satu sama lain, juga menuntut kehadiran negara (pemerintah dan aparat penegak hukum) untuk memastikan tegaknya peraturan perundang-undangan tersebut secara adil dan tidak diskriminatif, jauh dari tekanan massa sebagaimana sekarang terjadi di Indonesia.

Politik hukum pemenuhan (to fulfill) melalui sejumlah peraturan perundangundangan yang dikeluarkan di era pasca Orde Baru ternyata tidak diikuti dengan politik hukum perlindungan (to protect) dari negara. Pada bagian tertentu negara lemah berhadapan dengan tekanan massa dan gagal melindungi kebebasan beragama kaum minoritas; pada bagian lain negara membiarkan (by omission) tindakan kelompok mayoritas menekan, mengancam bahkan mengusir kelompok minoritas; dan pada bagian tertentu lainnya negara justru menjadi pelaku pelanggaran (by commission) dengan melarang kelompok menoritas melakukan ibadah ata mendirikan rumah ibadah atau menyeret individu atau kelompok dengan ancaman Pasal 165A.

\section{Penutup}

Berdasarkan uraian di atas, dapat disimpulkan sebagai berikut: Pertama, politik hukum HAM kebebasan beragama di Indonesia paska Orde Baru di level pemenuhan berupa pembuatan regulasi (peraturan perundang-undangan) relatif lebih maju dan lebih protektif karena dimuat ekspelisit dalam Pasal 28E ayat (1 dan 2) serta Pasal 281 (1) dan Pasal 29 UUD NRI 1945; dalam Pasal 22 UU No. 39 Tahun 1999 tentang HAM; Pasal 18 ayat (1 dan 2) UU No. 12 Tahun 2005 tentang hak sipil dan hak politik; Peraturan Presiden (Perpres) No. 7 Tahun 2005 tentang Rencana Pembangunan Jangka Menengah Nasional 2004-2009 yang di dalamnya diatur tentang peningkatan kerukunan intern dan antarumat beragama; Peraturan Bersama (PBM) Menteri Agama dan Menteri Dalam Negeri No. 9 dan 8 Tahun 2006 tentang Pedoman Pelaksanaan Tugas Kepala daerah/Wakil Kepala Daerah Dalam Pemeliharaan Kerukunan Umat Beragama, Pemberdayaan Forum Umat beragama, 
dan Pendirian Rumah Ibadat, atau dikenal dengan Forum Kerukunan Umat Beragama (FKUB); UU No. No. 23 Tahun 2006 tentang Adminsitrasi Kependudukan; UU No. 20 Tahun 2003 tentang Pendidikan Nasional yang menegaskan setiap orang berhak mendapatkan pendidikan agama dan beribadah menurut agamanya, berpikir, dan berekspresi sesuai dengan tingkat kecerdasan dan usianya, dalam bimbingan orang tua; dan UU No. 23 Tahun 2002 tentang Perlindungan Anak yang berhak menunaikan ibadah sesuai dengan ajaran agamanya.

Kedua, menguatnya politik hukum HAM kebebasan beragama di tingkat pembuatan peraturan perundang-undangan ternyata dalam realitasnya tidak diikuti dengan perubahan peraturan perundang-undangan di bawahnya, yaitu masih dipertahankannya PNPS No. 1 Tahun 1965dan Pasal 156a KUHP. Kedua UU tersebut selalu digunakan aparat penegak hukum pidana menjerat individu dengan tuduhan menistakan agama. Penggunaan Pasal inipun dalam banyak kasus bukan murni inisiatif Polisi dalam penegakan hukum, tetapi hasil tekanan massa. Pada bagian lain, pemerintah pusat dan pemerintah daerah cenderung saling lempar tanggungjawab, bahkan dalam sejumlah peristiwa pemerintah daerah menjadi pihak yang dilaporkan ke Komnas HAM sebagai pelaku pelanggaran hak kebebasan beragama; satu diantarnya karena kebijakan dan tindakan pemerintah daerah lebih tajam kepada kelompok minoritas dan longgar terhadap kelompok mayoritas.

Politik hukum HAM tentang kebebasan beragama ke depan harus diwujudkan dalam bentuk regulasi yang kuat, konsisten, harmonis dan sinkron satu sama lain, juga menuntut kehadiran negara (pemerintah dan aparat penegak hukum) untuk memastikan tegaknya peraturan perundang-undangan tersebut secara adil dan tidak diskriminatif, jauh dari tekanan massa sebagaimana sekarang terjadi sehingga kebebasan beragama di level internum dan eksternum dapat dikelola oleh negara secara adil, tidak diskirminatif, dan (yang jauh lebih penting) tidak ada lagi kekuatan massa mayoritas menekan negara untuk bertindak tidak adil terhadap kelompok minoritas.

Pemerintah memikul dua fungsi signifikan, yakni fungsi menjamin dan fungsi mengatur. Pemerintah harus mengakui dan menjamin hak setiap orang 
untuk meyakini dan memeluk agama/kepercayaan apapun (the right to be), meskipun pengakuan pemerintah bukan menjadi syarat mutlak bagi keberadaan hak setiap orang untuk memilih keyakinannnya — sebab hak tersebut telah inheran pada diri setiap individu sejak dia terlahir ke dunia-pemberian jaminan kepada hak berkeyakinan oleh negara ini sangat diperlukan demi memastikan bahwa hak tersebut dapat terealisasikan secara sempurna. Selain itu, pemerintah juga harus mengatur hak setiap orang untuk memanifestasikan keyakinannya (the right to act) agar tidak terjadi benturan dan konflik di tingkat masyarakat, ${ }^{69}$ hak atas keyakinan agama tidak bisa dipisahkan dengan hak menjalankan agama yang diyakininya itu.

\section{Daftar Pustaka}

\section{Buku}

Adji, Oemar Seno, Perkembangan Hukum Pidana dan Hukum Acara Pidana Sekarang dan di masa jang akan Datang, Pantjuran Tuju, Jakarta, 1983.

Cholil, Suhadi (ed), Momentum Baru Kebebasan Beragama, Resonansi (Dialog Agama dan Budaya): Dari Kebebasan Beragama, Pendidikan Multikultural, sampai RUU Anti Pornografi, CRCS Sekolah Pascasarjana UGM, Yogyakarta, 2008

Habermas, Jurgen, Religious Tolerance: The Pacemaker for Cultural Rights, Cambridge University Press, 2004.

Hartono, Sunaryati, Politik Hukum Menuju Satu Sistem Hukum Nasional, Alumni, Bandung, 1991.

Komnas HAM, Komentar Umum Kovenan Internasional Hak Sipil Politik Hak Ekonomi, Sosial dan Budaya, Komnas HAM, Jakarta, 2009

Lerner, Natan, Sifat dan Standar Minimun Kebebasan Beragama atau Berkeyakinan, Kebebasan Beragama dan Berkeyakinan Seberapa Jauh?, Kanisius, Yoyakarta, 2010.

MD, Mahfud, Politik Hukum Di Indonesia, Rajawali Pers, Jakarta, 2009. Membangun Politik Menegakkan Konstitusi, Rajawali Pers, Jakarta, 2010.

Soedarto, Hukum Pidana dan Perkembangan Masyarakat dalam Kajian Hukum Pidana, Sinar Baru, Bandung, 1983.

Soedarto, Hukum dan Hukum Pidana, Alumni, Bandung, 1986.

Rahardjo, Satjipto, Ilmu Hukum, Citra Aditya Bakti, Bandung, 2000.

${ }^{69}$ Momentum Baru Kebebasan Beragamae, editorial, dalam Suhadi Cholil, ed., Resonansi (Dialog Agama dan Budaya): Dari Kebebasan Beragama, Pendidikan Multikultural, sampai RUU Anti Pornografi, CRCS Sekolah Pascasarjana UGM, Yogyakarta, 2008, hlm. 79. 
Wignjosoebroto, Soetandyo, Dari Hukum Kolonial ke Hukum Nasional, Rajawali, Jakarta, 1994

\section{Jurnal, Majalah, Karya Ilmiah, Laporan Tahunan}

Abdullah, M. Amin, "Kebebasan Beragama atau Berkeyakinan Dalam Perspektif Kemanusiaan Universal, Agama-agama dan Keindonesiaan", makalah, disampikan pada Training HAM Lanjutan Untuk Dosen Hukum dan HAM, kerjasama Pusat Studi HAM Universitas Islam Indonesia dan Norwegian Centre For Human rigth, Yogyakarta, 8-10 Juni 2011.

Asy'ari, Hasyim, "Politik Hukum Kebebasan Beragama di Indonesia", dalam Jurnal Hukum Pandecta, Vol. 6, No. 1, Januari 2011, Fakultas Hukum Universitas Diponegoro, Semarang, 2011.

Firdaus, Muhammad Anang, “Eksistensi FKUB dalam Memelihara Kerukunan Umat Beragama di Indonesia"s, Kontekstualita, Vol. 29, No.1, 2014.

Laporan Akhir Tahun Pelapor Khusus Kebebasan Beragama dan Berkeyakinan Komsi Nasional Hak Asasi Manusia, Tahun 2015 dan 2016

Laporan Tahunan Kebebasan Beragama dan Berkeyakinan, Komnas HAM, Tahun 2016

MD, Mahfud, "Perkembangan Politik Hukum: Studi Tentang Pengaruh Konfigurasi Politik Terhadap Karakter Produk Hukum”, Disertasi, 1993.

The Indonesian Institute, Policy Brief, Maret 2015

Widodo, Rusman, “Editorial”, dalam Jurnal HAM, Komnas HAM, Jakarta, Volume VI tahun 2010.

The Wahid Institue, Laporan tahunan, 2015.

\section{Peraturan Perundang-Undangan, Konvensi Internasional, Putusan Pengadilan}

Undang-Undang Dasar Negara Republik Indonesia Tahun 1945

Kitab Undang-Undang Hukum Pidana

Undang-Undang No. 1/PNPS Tahun 1965 tentang Pencegahan Penyalahgunaan dan/atau Penodaan Agama

Undang-Undang Nomor 29 Tahun 1999 tentang Hak Asasi Manusia

Undang-Undang Nomor 12 Tahun 2005 tentang Ratifikasi Kovenan Internasional Tentang Hak-Hak Sipil dan Politik (International Covenant on Civil and Political Rights).

Undang-Undang Nomor 23 Tahun 2002 tentang Perlindungan Anak

Undang-Undang Nomor 20 Tahun 2003 tentang Pendidikan Nasional

Undang-Undang Nomor 23 Tahun 2006 tentang Adminsitrasi Kependudukan

Undang-Undang Nomor 26 Tahun 2007 tentang Penataan Ruang

Undang-Undang Nomor 23 Tahun 2014 tentang Pemerintahan Daerah 
Peraturan Presiden (Perpres) No. 7 Tahun 2005 tentang Rencana Pembangunan Jangka Menengah Nasional 2004-2009

Peraturan Bersama (PBM) Menteri Agama dan Menteri Dalam Negeri No. 9 dan 8 Tahun 2006 tentang Pedoman Pelaksanaan Tugas Kepala daerah/Wakil Kepala Daerah Dalam Pemeliharaan Kerukunan Umat Beragama, Pemberdayaan Forum Umat beragama, dan Pendirian Rumah Ibadat

Komentar Umum No. 22 tentang Kovenan Hak Sipil dan Politik

Putusan MK No. 140/PUU-VII/2009. 